\section{Fedotova, Elena Dmitrievna} Research Institute of Theory and History of Fine Arts of the Russian Academy of Arts, Moscow, Russian Federation

\section{Федотова Елена Дмитриевна}

Научно-исследовательский институт теории и истории изобразительных искусств Российской академии художеств, г. Москва, Российская Федерация

\title{
О ВЕЛИКОМ ДЕЛЕ «СОБИРАНИЯ ИСКУССТВ»
}

ON THE IMPORTANT ACTIVITY OF ART COLLECTING 


\section{Искусство Евразии}

\section{№4 (19) 2020 elSSN 2518-7767}

\section{АННОТАЦИЯ}

Статья представляет собой вступительное слово к конференции «Из истории собирательства: меценаты, коллекционеры, основатели музеев", организованной Российской академией художеств. Обращение автора к участникам посвящено краткому рассказу о людях, чьи имена связаны с понятием «благотворительность», меценатах, коллекционерах, основателях музеев России и зарубежных стран. Это известные личности разных национальных школ, своими деяниями прославившиеся на поприще заботы о сохранении культурного наследия. Цель конференции - вспомнить их имена и благородную деятельность.

\section{КЛЮЧЕВЫЕ СЛОВА:}

Благотворительность; меценатство; меценаты; коллекционеры; основатели музеев; созидание в области изобразительных искусств.

\section{ABSTRACT}

The article is an introduction to the conference "From the history of collecting: patrons, collectors, founders of museums", organized by the Russian Academy of Arts. The author's address to the participants is devoted to a short story about people whose names are associated with the concept of "charity" - patrons, collectors, founders of museums in Russia and abroad. These are wellknown personalities of various national schools, who became famous for their deeds in the field of caring for the preservation of cultural heritage. The purpose of the conference is to remember their names and noble activities.

\section{KEYWORDS:}

Charity; arts patronage; patrons of the arts; collectors; founders of museums; creation in the field of fine arts. 


\section{Интерес «Нравственное богатство народа наглядно исчисляется памятниками деяний на общее благо» B.О. Ключевский}

Научно-исследовательский институт теории и истории изобразительных искусств Российской академии художеств организовал конференцию «Из истории собирательства: меценаты, коллекционеры, основатели музеев», чтобы вспомнить людей, деяния которых называются одним словом - «благотворительность (благотворительство)». Они - образец искреннего и преданного служения делу культурного созидания. В «Толковом словаре» В.И. Даля их - меценатов, коллекционеров, основателей музеев - называют «подвижниками», то есть людьми, «славными великими делами на каком-либо поприще, доблестными деятелями» [1, с. 164]. Такие славные личности были во всех национальных школах, и мы попытаемся отдать дань памяти не только отечественным собирателям искусств, но и представителям зарубежных стран.

В России собирательство произведений изобразительного искусства, предметов русской старины (рукописей, духовной литературы, автографов, старопечатных книг, гравированных портретов исторических деятелей) имеет давнюю традицию. Вспомним Кунсткамеру - детище Петра I, имевшего «страсть изучать изящные науки и искусства», или коллекцию «курьезных вещей» генерал-фельдмаршала Я.В. Брюса. Защитники просветительских идеалов Елизавета Петровна и Екатерина II ратовали за установление связей с западноевропейским художественным миром, следуя завету Дидро собирать «вокруг себя знания и искусства». Коллекции находившихся на дипломатической службе графов Н.Б. Юсупова, Д.М. Голицына, президента Академии художеств П. Строганова, представителей дворянских родов - И.И. Шувалова, Б.П. Шереметева, А.А. Безбородко, Б.М. Хитрово, А.Б. Куракина и других, сконцентрированные в усадьбах и городских особняках, перерастали значение частных коллекций. На их основе возникли музеи-усадьбы «Архангельское», «Останкино», «Кусково», собрания Петергофа, Царского Села. Так возник Эрмитаж из частной коллекции императрицы, и само его название стало синонимом дворцового музея, а коллекция размещалась в павильоне Ж.-Б. Валлен-Деламота («Эрмитаж»), пристроенного к Зимнему дворцу. Частное собирательство всегда имело большое значение для музейного строительства, особенно в век Просвещения, когда тесные контакты с западноевропейскими странами, диалог собирателей были характерной чертой столетия. «Можно подумать, что русские богачи обобрали всю Европу» [2, с. 67],- писал один английский путешественник в конце XVIII века.
Портреты работы зарубежных живописцев донесли до нашего времени образы известных западноевропейских меценатов и коллекционеров, таких как Касьяно даль Поццо; Пьер-Жан Мариэтт; Эдвард Уортли Монтегю (посол Великобритании в Египте); знаток, графр де Келюс; лорд Уильям Гамильтон (посланник Великобритании в Южной Италии) и многих других. Собирателями были и просвещенные монархи, например Карлос III и Фердинанд IV из династии испанских Бурбонов, правящих в Южной Италии во второй половине XVIII столетия, создатели музеев в Портичи и в Каподимонте. В своих романтических дворцах-замках Людвиг I Баварский тоже хранил богатейшие собрания произведений искусства.

Беззаветное служение Отечеству демонстрировали в XIX столетии представители русского купечества и европейского предпринимательства. Они не только финансировали строительство банков, гостиниц, приютов, образовательных учреждений, театров, пассажей, издание журналов, но и благодаря страстному увлечению искусством, энергии, нравственной потребности становились обладателями великолепных коллекций. Семейнородовые собрания братьев Третьяковых, Щукиных, Бахрушиных, Боткиных, Морозовых стали основой для создания отечественных музеев. Начинание братьев Павла и Сергея Третьяковых, имевшее целью создание национальной общедоступной галереи, превратилось в крупнейший московский музей национального искусства, носящий имя этих двух подвижников из Замоскворечья. Павел Третьяков скромно называл себя «просто искренним любителем», полагая, что меценатство - общественно полезное дело. Благотворительность была кредо и семьи Бахрушиных. Младший из шести братьев - Алексей Александрович выискивал на Сухаревке и в Париже раритеты, связанные с театральным искусством. Дом Бахрушина у Зацепского вала стал с 1913 года общедоступным Музеем театрального искусства, носящим имя его создателя. Творчески одаренного Савву Ивановича Мамонтова, увлекавшегося оперным искусством, умевшего «углядеть» талантливых живописцев для своих постановок, создавшего в усадьбе «Абрамцево» центр духовной жизни в России, Ф.И. Шаляпин назвал «благородным, просвещенным деятелем» [3, с. 303]. Многих из этих выдающихся людей, радевших за отечественную культуру, мы видим на портретах И. Репина, М. Врубеля, В. Серова. Благодаря, например, увлечению коллекционированием Ивана Абрамовича Морозова мы имеем в России произведения Пикассо, Матисса, Моне, которые он передал в Музей искусства, находившийся до 1848 года на Пречистенке. А Сергей Морозов передал свою коллекцию Кустарному музею (ныне Музей декоративно-прикладного 
искусства в Леонтьевском переулке в Москве). Следует вспомнить и Степана Рябушинского, собирателя икон, имевшего реставрационные мастерские.

С Петровской эпохи ведет свое начало собирание рукописей и старопечатных книг. Народным достоянием стали собрания канцлера Н.П. Румянцева, мечтавшего об учреждении Русского национального музея и большой национальной библиотеки, которые стали бы «источником познаний о состоянии Отечества». Видными библиосилами были граср Алексей Иванович Мусин-Пушкин, обладатель, к сожалению, сгоревшего в 1812 году первого экземпляра «Слова о полку Игореве», а также Дм.М. Голицын, собиравший издания на иностранных языках, фабрикант-миллионер Алексей Хлудов, обладатель «Хлудовской Псалтири», купцы-миллионеры Козьма Солдатенков, имевший свою издательскую фирму, и Гаврила Солодовников, кстати, владевший ныне хранящимся в ГМИИ им. А.С. Пушкина полотном «Обнаженная» О. Ренуара. Без этих собирателей мы бы не имели столь блестящих собраний книг в наших крупнейших библиотечных и музейных фондах.

Проектов основания художественных музеев в России всегда было немало. Графом Николаем Александровичем Кушелевым-Безбородко, вельможей Екатерининской эпохи, был создан проект создания «Кушелевской галереи», с 1863 года размещавшейся в Императорской Академии художеств в Санкт-Петербурге. «Русскую картинную галерею» хотел создать и издатель журнала «Отечественные записки» Павел Петрович Свиньин. Выдающимся начинанием профессора Ивана Владимировича Цветаева стало создание «Музея изящных искусств им. Александра III». Идею Цветаева финансово поддержал Юрий Степанович Нечаев-Мальцов, помощник великого князя Сергея Александровича. Акционерами в создании музея были и представители семейства князей Юсуповых. Благодаря деятельности этих меценатов возникло на Волхонке выстроенное Романом Клейном здание с прекрасной мраморной колоннадой, с залами, отделанными мрамором, бронзовыми копиями «дверей» Гиберти, слепками, поиском которых в Европе занимался Цветаев, а деньги жертвовали отечественные меценаты.

С меценатством в организации выставок были связаны еще два деятеля отечественной культуры, имена которых следовало бы упомянуть. Это С.П. Дягилев, первым организовавший в 1896 году в России выставку скандинавских художников и познакомивший публику с работами Э. Мунка, А. Цорна и других. А также запечатленная на портрете И.Е. Репина княгиня М.К. Тенишева, проводившая выставки изделий художественных ремесел в Талашкине.
Существовали и другие новаторские концепции создания музея. Например, «Московского музея живописной культуры", целью основания которого в 1912 году (он просуществовал до 1929 года) было сохранение наследия отечественного авангарда, создание музея-лаборатории искусства нового типа, в своей основе антибуржуазного и антиакадемического. Благодаря собранию закупленных в эти годы произведений авангардистов значительно пополнились фонды Государственной Третьяковской галереи. О Музее современного искусства, как известно, мечтали В. Кандинский и К. Малевич.

Отрадно, что в наши дни наблюдается большой интерес к истории собирательства: проводятся выставки, посвященные известным коллекционерам (братьям Щукиным, Павлу Строганову и др.). Издан в 2007 году интересный и полезный труд «Собиратели и хранители прекрасного. Энциклопедический словарь российских коллекционеров от Петра I до Николая II. 1700-1918». Немало важных начинаний исходит от института меценатства, в том числе, например, издание книг и журналов, реставрация памятников архитектуры, создание частных музеев (Музей иконы, Музей Фаберже, Музей русского импрессионизма, Музей русского реалистического искусства). Что движет современными меценатами, коллекционерами, основателями музеев? Хочется думать, что любовь к художеству, желание сохранить память о национальном наследии, просветительство. Пусть появляются новые Третьяковы, Морозовы, Щукины, Мамонтовы, Бахрушины, Боткины с их страстным интересом к собирательству, но собирательству во славу нашей культуры, нашего Отечества. Таким «доблестным деятелям», если использовать определение В.И. Даля, мы, историки искусства, всегда рады. Для разговора о них мы и предприняли наш широкий экскурс в историю собирательства, которое возвышает душу. 


\section{Литература}

1. Даль В.И. Толковый словарь живого великорусского языка. В 4 тт. Москва: ГИС, 1956. Т. 3. 555 с.

2. Карнович Е.П. Замечательные богатства частных лиц в России. Санкт-Петербург: Тип. К.Н. Плотникова, 1874.380 с.

3. Федор Иванович Шаляпин [Сборник]: В 3 т. Т. 3: Статьи и высказывания. / Ред.-сост. Е.А. Грошева. Москва: Искусство, 1979.392 с.

\section{References}

1. Dal V.I. Tolkovyi slovar' zhivogo velikorusskogo yazyka [Explanatory Dictionary of the Living Great Russian Language]. In 4 vols. Moscow, GIS, 1956. Vol. 3. 555 p. (In Russian)

2. Karnovich E.P. Zamechatel'nye bogatstva chastnykh lits $v$ Rossii [The remarkable wealth of individuals in Russia].

St. Petersburg, Tipografiya K.N. Plotnikova, 1874. 380 p. (In Russian)

3. Grosheva E.A. (ed.). Fedor Ivanovich Shalyapin [Feodor Ivanovich Chaliapin. Collection in 3 volumes]. Vol. 3: Articles and statements. Moscow, Iskusstvo, 1979. 392 p. (In Russian)

ИНФОРМАЦИЯ ОБ АВТОРЕ: Федотова Елена Дмитриевна - доктор искусствоведения, член-корреспондент Российской академии художеств, заведующий отделом зарубежного искусства, Научно-исследовательский институт теории и истории изобразительных искусств Российской академии художеств, г. Москва, Российская Федерация. E-mail: numero47@yandex.ru

ABOUT AUTHOR: Fedotova, Elena Dmitrievna - D.Sc. (Art History), corresponding member of the Russian Academy of Arts; Chief of the Department of foreign Art, the Research Institute of Theory and History of Fine Arts of the Russian Academy of Arts, Moscow, Russian Federation. E-mail: numero47@yandex.ru

\section{Для цитирования |For citation:}

Федотова Е.Д. О великом деле «собирания искусств» // Искусство Евразии [Электронный журнал]. 2020. № 4 (19). С. $129-133$. DOl: https://doi.org/10.46748/ARTEURAS.2020.04.010. URL: https://eurasia-art.ru/index.php/art/article/view/147

Fedotova E.D. On the important activity of art collecting. Iskusstvo Evrazii - The Art of Eurasia, 2020, No. 4 (19), pp. 129-133. DOI: https://doi.org/10.46748/ARTEURAS.2020.04.010. Available at: https://eurasia-art.ru/index.php/art/article/view/147 (In Russian). 